THE FATE OF THE CORPS

- 



\title{
The Fate of the Corps
}

\author{
What Became of the
}

Lewis and Clark Explorers

After the Expedition

L A R R Y E M O R R I S
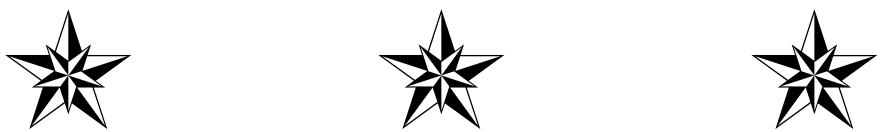

YALE UNIVERSITY PRESS NEW HAVEN \& LONDON 
Parts of this book were adapted from the author's article "Dependable John Ordway," We Proceeded On 27, May 20or; used by permission. Parts of this book were adapted for the article "After the Expedition," American History, April 2003.

\section{Copyright (C) 2004 by Larry Morris.}

All rights reserved.

This book may not be reproduced, in whole or in part, including illustrations, in any form (beyond that copying permitted by Sections I07 and I08 of the U.S. Copyright Law and except by reviewers for the public press), without written permission from the publishers.

Designed by James J. Johnson and set in Bulmer \& Baskerville types by Integrated Publishing Solutions.

Printed in the United States of America by R.R. Donnelley \& Sons.

\section{Library of Congress Cataloging-in-Publication Data}

Morris, Larry E., I95 I-

The fate of the corps : what became of the Lewis and Clark explorers after the expedition / Larry E. Morris.

p. $\quad \mathrm{cm}$.

Includes bibliographical references and index.

ISBN o-300-I0265-8 (alk. paper)

I. Lewis and Clark Expedition (I804-I806) 2. Explorers-West (U.S.)-Biography.

3. Lewis, Meriwether, I774-1809. 4. Lewis, Meriwether, I774-1809-Friends and associates. 5. Clark, William, I770-1838. 6. Clark, William, I770-I838 - Friends and associates. I. Title

$$
\begin{gathered}
\mathrm{F}_{592.7 . \mathrm{M} 685} 2004 \\
917.804^{\prime} 2-\mathrm{dc} 22 \\
2004000196
\end{gathered}
$$

A catalogue record for this book is available from the British Library.

The paper in this book meets the guidelines for permanence and durability of the Committee on Production Guidelines for Book Longevity of the Council on Library Resources. 
To Richard Lloyd Anderson 

"I tried to tell her how if you could not accept the past and its burden there was no future, for without one there cannot be the other, and how if you could accept the past you might hope for the future, for only out of the past can you make the future."

- Robert Penn Warren, All the King's Men 
